\title{
PENGUKURAN RESIKO TEKNOLOGI INFORMASI DENGAN PENDEKATAN FRAP: STUDI KASUS PADA PT COWELL DEVELOPMENT, TBK
}

\author{
Iwan Kurniawan Widjaya \\ Computerized Accounting Department, School of Information Systems, Binus University \\ Jln. K.H. Syahdan No. 9, Palmerah, Jakarta Barat 11480 \\ iwkkvk2011@yahoo.co.id; iwankw@binus.ac.id
}

\begin{abstract}
The article purposes are to analyze, identify, and measure the risks found in the use of information technology. The research method used are literature study and field study upon observations, interviews, documentation, and FRAP (facilitated Risk Analysis Process) approach to measure the risk of information technology. The results found are positive and negative findings in the use of information technology. The exixting weaknesses allow the potential risks that may occur. The conclusion is there are vulnerabilities found in the use of information technology that need several recommendations on those risks to improve performance and guarantee data protection and information from any risk arise.
\end{abstract}

Keywords: risk, risk measurement, information technology, FRAP

\begin{abstract}
ABSTRAK
Tujuan artikel ini adalah menganalisis, mengidentifikasi, dan mengukur resiko-resiko resiko-resiko yang ditemukan atas penggunaan teknologi informasi. Metode penelitian yang digunakan adalah studi pustaka dan studi lapangan berupa observasi, wawancara, dan dokumentasi, serta pendekatan FRAP (Facilitated Risk Analysis Process) untuk mengukur resiko teknologi informasi. Hasil yang dicapai adalah temuan kelebihan dan kelemahan dalam penggunaan teknologi informasi. Kelemahan yang ada memungkinkan adanya potensi resiko yang dapat terjadi. Simpulan yang diperoleh adalah ditemukannya kerentanan dalam penggunaan teknologi informasi di perusahaan sehingga diperlukan rekomendasi terhadap resiko tersebut untuk meningkatkan kinerja, dan menjamin terlindungnya data dan informasi dari setiap resiko yang muncul.
\end{abstract}

Kata kunci: resiko, pengukuran resiko, teknologi informasi, FRAP 


\section{PENDAHULUAN}

Informasi teknologi, termasuk juga sistem informasi berbasis internet, saat ini merupakan suatu hal yang memainkan peranan vital dan sangat membantu dalam memperluas serta memajukan bisnis. Teknologi informasi dapat membantu segala jenis bisnis karena dapat meningkatkan efisiensi dan efektifitas proses bisnis, pengambilan keputusan manajerial, dan kolaborasi kelompok kerja (workgroup), sehingga hal tersebut dapat memperkuat posisi kompetitif bisnis perusahaan di pasar yang cepat sekali mengalami perubahan. Teknologi informasi ini juga digunakan untuk mendukung pengembangan produk, proses dukungan pelanggan, transaksi perdagangan elektronik (e-commerce), ataupun aktivitas bisnis lainnya. Teknologi informasi atau sistem informasi berbasis internet telah menjadi sebuah kebutuhan penting dalam kesuksesan di era perkembangan global saat ini (O’Brien \& Marakas, 2007).

Jika teknologi informasi adalah hal yang akan memberikan dukungan tambahan bagi perusahaan maka resiko adalah hal yang bersifat kontraproduktif bagi perusahaan. Resiko merupakan ketidakpastian yang mungkin melahirkan peristiwa kerugian (Djojosoedarso, 2005).

Dengan adanya suatu manajemen resiko, resiko-resiko yang ada dapat dihilangkan, dikurangi, ataupun ditransfer. Oleh karena itu manajemen resiko di dalam suatu perusahaan amat penting dan dapat menghindari perusahaan dari kerugian-kerugian yang mungkin timbul di masa mendatang yang berasal dari resiko-resiko yang tidak dijadikan titik fokus di masa sekarang. (Gondodiyoto, 2009).

Tujuan penelitian adalah mengidentifikasi resiko-resiko yang ditemukan atas penggunaan teknologi informasi; melakukan pengukuran resiko terhadap teknologi informasi yang sudah diterapkan; mengetahui apakah di dalam perusahaan, penerapan teknologi informasi sudah memiliki peranan yang penting; mengidentifikasi praktek keamanan dan memberikan solusi yang terbaik untuk mengelola dan menanggulangi resiko. Manfaat penelitian ini yaitu memberikan informasi kepada perusahaan mengenai resiko yang ada pada teknologi informasi yang diterapkan; hasil penelitian dapat digunakan perusahaan untuk menyempunakan penerapan teknologi informasi perusahaan; memberikan alternatif solusi terhadap kelemahan atau resiko teknologi informasi perusahaan dan juga untuk mengurangi kerugian yang mungkin terjadi.

\section{METODE}

Pendekatan yang digunakan oleh penulis untuk melakukan resiko TI bersifat kualitatif. Metode yang dipakai berupa studi kasus pada PT Cowell Development, Tbk, antara lain:

\section{Teknik Pengumpulan Data}

Dalam penyusunan artikel ilmiah ini, data-data yang diperlukan diperoleh dari teknik pengumpulan data, sebagai berikut: (1) riset kepustakaan, yaitu dengan mengumpulkan data yang menggunakan sumber berupa buku atau bahan dari perpustakaan serta membaca literatur via website sebagai panduan dalam menyusun artikel ilmiah; (2) riset lapangan, yaitu dengan meninjau langsung ke PT Cowell Development, Tbk dengan tujuan untuk memperoleh data yang dibutuhkan untuk penelitian. Adapun caranya sebagai berikut: (a) wawancara (interview), dengan cara tanya jawab secara langsung melalui pihak yang berkepentingan dalam perusahaan sehingga didapatkan data yang tepat dan berkualitas; (b) pengamatan (observasi), dengan meninjau secara langsung terhadap objek yang akan diteliti penulis disini berkaitan dengan kondisi TI yang dipakai perusahaan yang mencakup hardware, software, jaringan, aplikasi, dan prosedur yang diterapkan perusahaan. 


\section{Teknik Analisis}

Ada berbagai metode dan pendekatan dalam menganalisis resiko salah satunya adalah FRAP (Facilitated Risk Analysis Process) (Peltier, 2001). FRAP merupakan suatu pendekatan dalam melakukan analisis resiko kualitatif. FRAP dikembangkan sebagai proses yang efisien dan disiplin untuk menjamin resiko informasi terkait keamanan yang berhubungan dengan operasi bisnis dipertimbangkan dan didokumentasikan. Dengan menggunakan FRAP diharapkan proses analisis resiko dapat dilakukan dalam hitungan hari, bukan mingguan atau bulanan. Dengan demikian analisis resiko bukan merupakan kendala, tetapi proses yang sangat mungkin dilakukan dan juga diperlukan. FRAP bukan suatu metodologi, tetapi suatu pendekatan terhadap proses penentuan resiko dan dampaknya, proses penentuan prioritas, dan proses penentuan kontrol pengamanan. Pendekatan FRAP (Facilitated Risk Analysis Process) adalah bentuk pendekatan analisis resiko kualitatif yang paling banyak digunakan saat ini. Dari teknik yang ada untuk mengukur resiko teknologi informasi, penulis memutuskan untuk menggunakan pendekatan FRAP.

FRAP (Peltier, 2001) dikembangkan sebagai proses yang efisien dan disiplin untuk menjamin resiko informasi terkait keamanan yang berhubungan dengan operasi bisnis dipertimbangkan dan didokumentasikan. Prosesnya melibatkan penganalisisan satu sistem, aplikasi, atau segmen dari operasi bisnis pada satu waktu dan mengumpulkan sebuah tim dari individu-individu termasuk manajer bisnis yang akrab dengan kebutuhan informasi bisnis dan staf teknis yang memiliki pemahaman yang rinci tentang kelemahan sistem yang potensial dan terkait kontrol.

Selama sesi FRAP, tim mengungkapkan pendapat tentang ancaman yang potensial, vulnerability, dan hasil dari dampak negatif pada integrity data, confidentiality, serta availability. Lalu tim akan menganalisis pengaruh dampak tersebut terhadap operasi bisnis dan secara luas mengkategorikan resiko menurut prioritas levelnya. Tim biasanya tidak mencoba untuk mendapatkan atau mengembangkan angka yang spesifik untuk kemungkinan terjadinya ancaman atau perkiraan kerugian tahunan meskipun data untuk menentukan faktor-faktor tersebut tersedia. Tim bergantung pada pengetahuan umum dari ancaman dan kerentanan yang diperoleh dari pusat respon insiden nasional, asosiasi profesi dan literatur, dan pengalaman mereka sendiri.

Setelah mengidentifikasi dan mengkategorikan resiko, tim mengidentifikasi pengendalianpengendalian yang dapat diimplementasikan untuk mengurangi resiko, berfokus pada pengendalian yang paling efektif dari segi biaya. Tim akan menggunakan titik awal dari 26 kontrol umum yang dirancang untuk mengatasi berbagai jenis resiko. Pada akhirnya, keputusan seperti apa yang dibutuhkan terkait pengendalian terletak pada manajer bisnis yang mempertimbangkan sifat aset-aset informasi dan pentingnya mereka bagi operasi bisnis dan biaya pengendalian.

Kesimpulan tim mengenai resiko-resiko apa yang ada, bagaimana prioritasnya, dan pengendalian apa yang yang dibutuhkan, didokumentasikan dan dikirim kepada pimpinan proyek dan manajer bisnis untuk menyelesaikan rencana aksi.

Tiap proses analisis resiko (Peltier, 2001) dibagi menjadi tiga sesi yang berbeda: pre-FRAP meeting, FRAP session, dan post-FRAP session.

\section{Pre-FRAP Meeting}

Pre-FRAP meeting ini merupakan kunci sukses dalam suatu proyek. Pada tahap ini pertemuan biasanya berlangsung sekitar satu jam dan biasanya dilakukan di kantor klien.

Ada 5 komponen utama yang muncul dari sesi ini: (1) scope statement - pimpinan proyek dan manajer bisnis harus menentukan ruang lingkup pembahasan; (2) visual model - pembuatan diagram 
proses (gambaran) mengenai pernyataan ruang lingkup untuk ditinjau kembali; (3) team members membangun tim FRAP yang terdiri atas tujuh hingga 15 orang anggota yang berhubungan dengan sistem yang terkait; (3) meeting mechanics - manager bisnis bertanggung jawab dalam menyediakan ruangan meeting, menyusun jadwal, dan juga menyiapkan bahan-bahan yang dibutuhkan; (4) agreement of definition - dalam sesi pre-FRAP dibutuhkan persetujuan terhadap definisi FRAP. Persetujuan tersebut haruslah berdasarkan pada adanya risk, control, impact, dan vulnerability. Selama sesi pre-FRAP sangatlah penting untuk mendiskusikan ancaman utama dalam proses bisnis.

\section{FRAP Session}

Pada tahap ini pertemuan biasanya berlangsung selama empat jam. Komponen-komponen yang muncul dari tahap ini di antaranya adalah: (1) identified risks - mengidenifikasi resiko yang mungkin terjadi pada sistem bisnis perusahaan; (2) priotized risks - menentukan resiko utama dari semua resiko yang mungkin terjadi (yang memilki ancaman terbesar); (3) suggested controls memberikan solusi pengendalian untuk meminimalisir resiko dan juga ancaman yang mungkin terjadi.

Definisi-definisi dalam tahap ini yang harus dipahami sebagai berikut: High vulnerability: tingkat kelemahan yang sangat besar yang ada di dalam sistem atau operasional perusahaan, dimana dampak potensi terhadap bisnis sangatlah besar dan signifikan, sehingga kontrolnya harus ditingkatkan.

Medium vulnerability: terdapatnya beberapa kelemahan yang muncul, dan ketika dampak potensi terhadap bisnis mulai muncul dengan tingkat yang besar atau signifikan, maka kontrolnya dapat lebih ditingkatkan.

Low vulnerability: sistem yang ada sudah dioperasikan dengan baik dan benar. Tidak dibutuhkannya kontrol untuk mengurangi kerentanan. Severe impact (high): dapat menjatuhkan usaha dari bisnis yang ada atau memberikan kerusakan yang parah terhadap prospek dan perkembangan perusahaan. Significant impact (medium): dapat mengakibatkan kerusakan dan kerugian biaya yang signifikan, tetapi usaha/ bisnis tetap akan bertahan. Minor impact (low): tipe dampak yang cukup operasional terhadap bisnis, dimana dampak ini tetap dikelola sebagai bagian dari rutinitas bisnis biasa. Berikut merupakan Matrix Prioritas dalam menganalisis aksi dan kontrol yang harus diimplementasikan berdasarkan tipe tinggi atau rendahnya dampak bisnis dan tingkat kerentanan yang dapat terjadi pada sistem perusahaan.

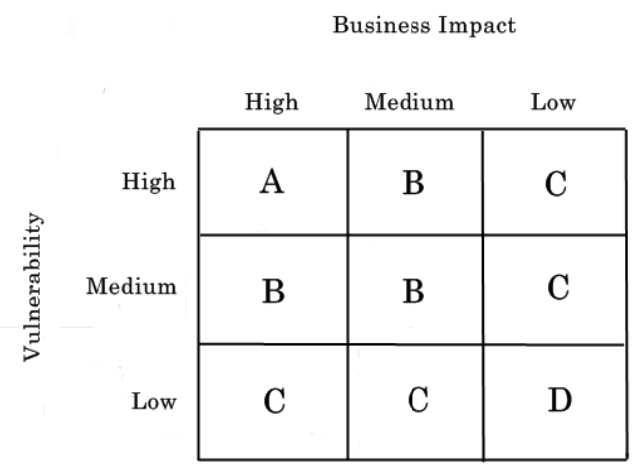

Gambar 1. Priority risk matrix.
A : Tindakan korektif harus diimplementasikan
B : Tindakan korektif sebaiknya diimplementasikan
C : Dibutuhkan monitoring (pengawasan)
D : Tidak ada tindakan yang diperlukan 


\section{Post-FRAP Meeting}

Pada tahap ini pertemuan biasanya berlangsung selama empat jam dan memiliki tiga elemen: (1) creation on the cross-reference sheet - membuat cross-reference sheet yang berisikan masingmasing kontrol dan resiko-resiko apa saja yang dapat berkurang sebagai akibat dari pelaksanaan kontrol tersebut; (2) identification of existing controls - meninjau ulang, mengidentifikasi kontrol apa saja yang dapat digunakan untuk mengatasi resiko-resiko yang masih terbuka; (3) selection of controls for open risks or acceptance of risk - menentukan control apa saja yang perlu dilakukan untuk menganggulangi resiko yang masih ada. Atau bahwa ternyata resiko tersebut tidaklah bersifat high impact sehingga bisnis manajer mengindikasikan resiko tersebut sebagai resiko yang dapat diterima.

\section{HASIL DAN PEMBAHASAN}

\section{Pre-FRAP Meeting}

\section{Ruang Lingkup}

Dalam pernyataan ruang lingkup ini kami sebagai fasilitator FRAP menentukan ruang lingkup mana saja yang akan diambil, dalam hal ini diambil ruang lingkup di bidang TI (Sistem informasi dan infrastruktur) dalam PT Cowell Development, Tbk. Akan tetapi bukan berarti tidak ada bagian lain yang terkait; ada keterkaitan secara tidak langsung seperti kepada Bagian Marketing dan Keuangan. Gambaran Proses FRAP (Gambar 2).

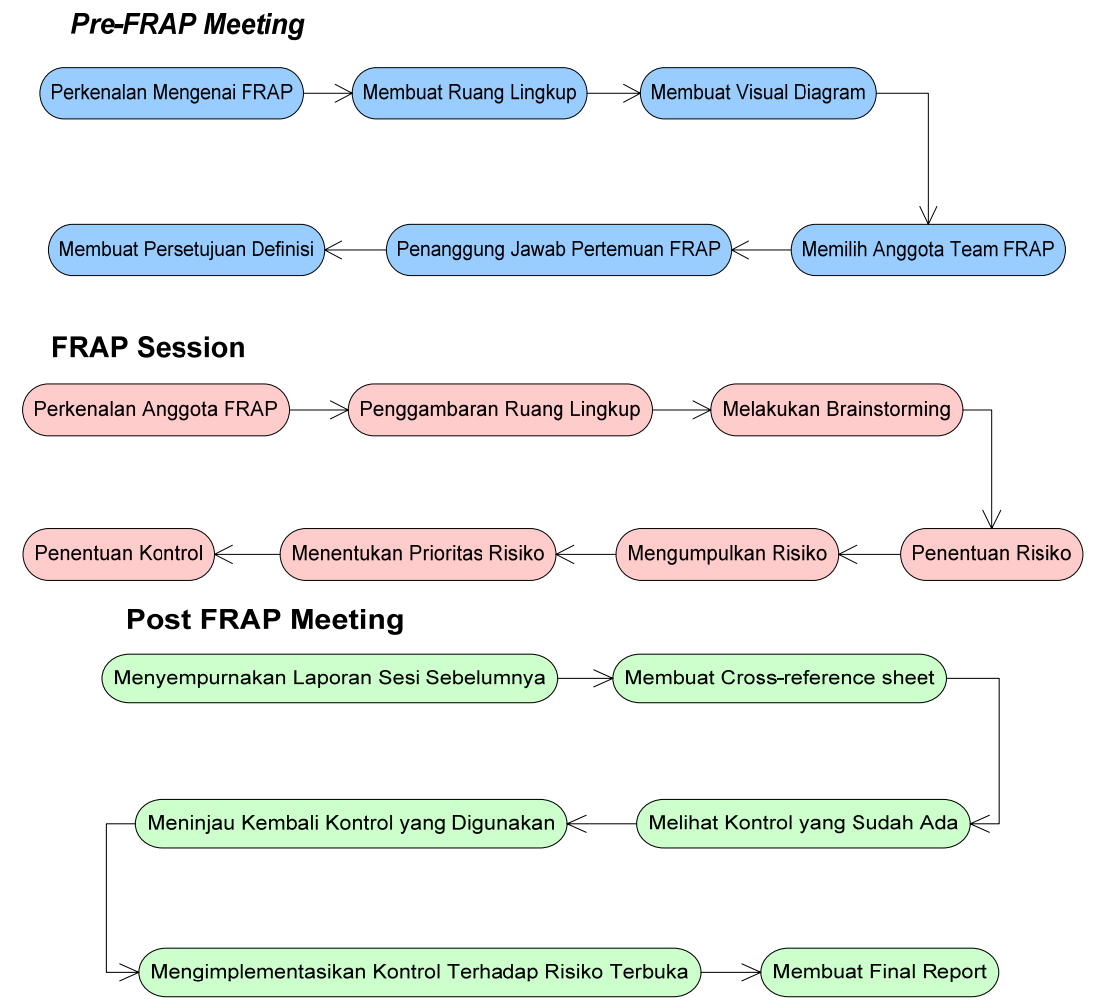

Gambar 2. Gambaran (visual model) proses FRAP. 


\section{Menentukan Anggota FRAP}

Selama proses FRAP Meeting ini Fasilitator FRAP perlu menentukan siapa saja yang terkait dalam FRAP Team, hal ini dapat membantu fasilitator dalam melakukan brainstorming terhadap resiko yang mungkin muncul, resiko yang telah muncul maupun kontrol yang telah ada. Adapun anggota yang melakukan brainstorming ini yaitu: General Manager TI, Kepala dari Sistem Informasi terkait, Kepala Infrakstruktur dan Jaringan, Staff TI, Manajer Bisnis, Pimpinan Proyek, Fasilitator, dan Juru tulis.

\section{Pertemuan Teknis}

Dalam proses Meeting Mechanics ini manajer bisnis memilih seseorang dari stafnya untuk bertanggung jawab terhadap ketersediaan ruang meeting, menentukan jadwal meeting serta menyiapkan kebutuhan yang diperlukan untuk jalannya meeting.

\section{Persetujuan Definisi}

Dalam tahap ini fasilitator perlu menentukan persetujuan terhadap definisi terhadap elemenelemen yang muncul pada resiko yaitu: (1) integrity - segala macam informasi tanpa adanya modifikasi yang tidak sah (asli); (2) confidentiality - informasi yang ada diperusahaan bersifat rahasia dan hanya pihak yang berwenang yang dapat mengakses dari informasi tersebut; (3) availability aplikasi, sistem, atau sumber informasi yang diperlukan oleh perusahaan tersedia saat dibutuhkan. Hendaknya seluruh anggota FRAP dapat mengerti dan memahami dengan pasti dari ketiga elemen tersebut.

\section{FRAP Session}

Berikut beberapa hal yang ditemukan mengenai identifikasi resiko (Tabel 1), kontrol terhadap resiko (Tabel 2), dan prioritasi resiko (Tabel 3).

Tabel 1

Identifikasi Resiko

\begin{tabular}{cl}
\hline No. & \multicolumn{1}{c}{ Resiko } \\
\hline 1 & Informasi diakses oleh pihak yang tidak berwenang \\
2 & Kurangnya proses internal untuk membuat dan mengendalikan, mengelola data di seluruh \\
3 & fungsi \\
4 & Dnformasi digunakan dalam konteks yang tidak sesuai \\
5 & Informasi pihak ketiga dapat menyebabkan masalah kepada perusahaan \\
6 & Otorisasi keaslian permintaan data \\
7 & Penolakan akses ke informasi padahal diakses oleh orang yang berwenang \\
8 & Penggunaan informasi yang tidak benar yang dapat berdampak pada bisnis \\
9 & Prosedur otorisasi pada perusahaan \\
10 & Proses kontrol yang terlalu rumit \\
11 & Kurangnya personil dibidang sistem aplikasi \\
12 & Informasi dikeluarkan tanpa otorisasi yang tepat \\
13 & Kebocoran informasi internal perusahaan \\
14 & Tidak menanggapi permintaan secara tepat waktu
\end{tabular}


Personil internal sengaja memodifikasi data untuk pribadi/keuntungan kelompok

\begin{tabular}{|c|c|}
\hline 16 & Tidak adanya kepercayaan bisnis dengan mitra pihak ketiga \\
\hline 17 & Tidak adanya rekaman terhadap perubahan sistem/aplikasi software \\
\hline 18 & Data lama/dokumen tidak dihapus \\
\hline 19 & Modifikasi anti virus terhadap perkembangan virus \\
\hline 20 & Kesalahan terhadap data/ dokumen yang dipublikasikan \\
\hline 21 & Informasi dari mitra atau pemasok terjadi kesalahan \\
\hline 22 & Informasi/ data tidak benar \\
\hline 23 & Salah pengelompokan informasi/data \\
\hline 24 & Akses terhadap pelanggan/mitra kerja tidak tersedia secara lengkap \\
\hline 25 & Mantan user/ karyawan masih memiliki akses untuk mengamankan data \\
\hline 26 & Menggunakan sistem yang rentan untuk mengirim data/ informasi yang penting \\
\hline 27 & Akses yang tidak terkendali terhadap informasi yang rahasia \\
\hline 28 & Informasi sensitif dan tidak sensitif menjadi satu \\
\hline 29 & Otentikasi untuk akses informasi sensitif tidak memadai \\
\hline 30 & Penyalahgunaan user id \\
\hline 31 & Akses untuk backup data tidak terkontrol dengan baik \\
\hline 32 & Keamanan firewall diintrusi \\
\hline 33 & Pihak ketiga membatalkan perjanjian yang telah dibuat \\
\hline 34 & Hacker dapat membuat sistem down \\
\hline 35 & Situs hosting tidak memiliki perlindungan fisik informasi \\
\hline 36 & Hubungan jaringan antar sistem gagal didalam perusahaan \\
\hline 37 & Desain sistem terlalu rumit \\
\hline 38 & Kesalahan terhadap instalasi software/hardware \\
\hline 39 & Kebutuhan backup tidak memadai \\
\hline 40 & Kesalahan konfigurasi hardware \\
\hline 41 & Kurangnya pelatihan bagi user \\
\hline 42 & Terdapatanya virus dapat menyebabkan kegagalan sistem/ hilangnya data \\
\hline 43 & Router yang tidak berfungsi dengan baik dapat menyebabkan sulitnya akses pada layanan \\
\hline 44 & Ketidaktersediaan dokumen DRP dalam perusahaan \\
\hline 45 & Tidak adanya Emergency Respon Procedure yang diimplementasikan di perusahaan \\
\hline
\end{tabular}

Tabel 2

Kontrol terhadap Resiko

\begin{tabular}{cll}
\hline No. & \multicolumn{1}{c}{ Kontrol } & \multicolumn{1}{c}{ Deskripsi Kontrol } \\
\hline 1 & Clear visualization & $\begin{array}{l}\text { Terdapat suatu proses bisnis yang lengkap sehingga memungkinkan bagi } \\
\text { perusahaan melihat gambaran secara jelas proses bisnis yang akan dijalankan. }\end{array}$ \\
\hline 2 & $\begin{array}{l}\text { Information } \\
\text { authorization }\end{array}$ & $\begin{array}{l}\text { Penggunaan informasi dalam perusahaan dipakai dengan cara yang tepat } \\
\text { karena setiap tindakan yang dilakukan berdasarkan arahan dari yang } \\
\text { berwenang dan tanpa adanya pemalsuan informasi (otorisasi yang tepat) }\end{array}$ \\
\hline 3 & Internal update & Data dalam perusahaan (internal) selalu diperbarui secara berkala. \\
\hline
\end{tabular}




\begin{tabular}{|c|c|c|}
\hline 4 & Confidential access & $\begin{array}{l}\text { Adanya sistem keamanan dalam sistem informasi sehingga tidak sembarang } \\
\text { orang dapat mengakses langsung dalam sistem (khususnya orang dari pihak } \\
\text { luar). }\end{array}$ \\
\hline 5 & Access authorization & $\begin{array}{l}\text { Setiap akses yang diberikan kepada karyawan perusahaan melalui ijin dari } \\
\text { atasan, dan selalu dikonfirmasi dengan baik kepada pengguna. }\end{array}$ \\
\hline 6 & Modify authorization & $\begin{array}{l}\text { Dalam mengupdate/memodifikasi data diperlukan surat perintah dari atasan, } \\
\text { tidak boleh sembarang merubah, menambah, ataupun menghilangkan data. }\end{array}$ \\
\hline 7 & Data classification & $\begin{array}{l}\text { Setiap data memiliki pengelompokannya masing-masing, dan secara teratur } \\
\text { dikordinasi oleh pihak TI. }\end{array}$ \\
\hline 8 & $\begin{array}{l}\text { Third party } \\
\text { communication clearly }\end{array}$ & Adanya komunikasi yang jelas dengan mitra kerja/pihak ketiga. \\
\hline 9 & Remove access & $\begin{array}{l}\text { Setiap pengguna yang telah keluar perusahaan (resign), akan langsung dicabut } \\
\text { aksesnya terhadap akses sistem informasi. }\end{array}$ \\
\hline 10 & Adequately network & $\begin{array}{l}\text { Sistem penyaluran informasi/akses dalam perusahaan memiliki kualitas yang } \\
\text { baik dan terjaga kerahasiaannya. }\end{array}$ \\
\hline 11 & Virus protected & $\begin{array}{l}\text { Setiap Laptop dan Personal Computer harus memiliki perlindungan Firewal } \\
\text { dan Antivirus yang sesuai standar perusahaan. }\end{array}$ \\
\hline 12 & Id requirment & Setiap pengguna memiliki satu ID user. \\
\hline 13 & $\begin{array}{l}\text { Disaster recovery } \\
\text { planning }\end{array}$ & $\begin{array}{l}\text { Rencana pemulihan dari kemungkinan kerusakan-kerusakan yang berdampak } \\
\text { pada kemampuan proses komputer dan operasi bisnis perusahaan. }\end{array}$ \\
\hline 14 & Good server quality & Perusahaan memiliki server yang baik dan memadai. \\
\hline 15 & $\begin{array}{l}\text { Good of Bussiness } \\
\text { Partner }\end{array}$ & Perusahaan memiliki mitra bisnis yang baik dan memadai. \\
\hline 16 & $\begin{array}{l}\text { Update of Operating } \\
\text { System }\end{array}$ & $\begin{array}{l}\text { Perusahaan mengikuti perkembangan zaman terhadap OS (operating system) } \\
\text { komputer. }\end{array}$ \\
\hline 17 & Backup & $\begin{array}{l}\text { Persyaratan cadangan akan ditentukan dan dikomunikasikan ke penyedia } \\
\text { layanan, termasuk permintaan bahwa pemberitahuan elektronik di mana } \\
\text { cadangan diselesaikan, dikirim ke administrator sistem aplikasi. Operasional } \\
\text { akan diminta untuk menguji prosedur cadangan. }\end{array}$ \\
\hline 18 & Recovery plan & $\begin{array}{l}\text { Mengembangkan, mendokumentasikan, dan menguji prosedur pemulihan yang } \\
\text { dirancang untuk merancang untuk memastikan bahwa aplikasi dan informas } \\
\text { dapat diperoleh kembali, dengan menggunakan cadangan yang dibuat, jika } \\
\text { terjadinya kemungkinan kehilangan data. }\end{array}$ \\
\hline 19 & Access control & $\begin{array}{l}\text { Menerapkan mekanisme kontrol akses untuk mencegah akses yang tidak sah } \\
\text { terhadap informasi. Mekanisme ini akan mencakup kemampuan untuk } \\
\text { mendeteksi, dan melaporkan pencobaan terhadap keamanan informasi. }\end{array}$ \\
\hline 20 & Access control & $\begin{array}{l}\text { Sumber akses adalah menerapkan mekanisme untuk membatasi akses ke } \\
\text { informasi rahasia dan ke jalur jaringan tertentu atau lokasi fisik. }\end{array}$ \\
\hline 21 & Access control & $\begin{array}{l}\text { Melaksanakan mekanisme otentikasi pengguna (seperti firewall, tombol/dial-in } \\
\text { kontrol, keamanan ID) untuk membatasi akses ke petugas yang berwenang. }\end{array}$ \\
\hline 22 & Access control & $\begin{array}{l}\text { Melaksanakan mekanisme enkripsi data untuk mencegah akses yang tidak sah } \\
\text { untuk melindungi integritas sebuah kerahasiaan informasi. }\end{array}$ \\
\hline 23 & Application control & $\begin{array}{l}\text { Merancang dan menerapkan pengendalian aplkasi (pengecekan pemasukan } \\
\text { data lapangan yang memerlukan validasi, indikator alarm, kemampuan sandi } \\
\text { kadaluarsa, pengecekan jumlah) untuk menjamin integritas, kerahasiaan, dan } \\
\text { ketersediaan informasi aplikasi. }\end{array}$ \\
\hline
\end{tabular}




\begin{tabular}{|c|c|c|}
\hline 24 & Acceptance testing & $\begin{array}{l}\text { Mengembangkan prosedur pengujian yang harus diikuti selama aplikasi dan } \\
\text { selama modifikasi aplikasi yang sudah ada yang mencakup penggunaan } \\
\text { partisipasi dan penerimaan. }\end{array}$ \\
\hline 25 & Change management & $\begin{array}{l}\text { Mematuhi suatu proses perubahan manajemen yang dirancang untuk } \\
\text { memfasilitasikan pendekatan struktur untuk modifikasi, untuk memastikan } \\
\text { langkah yang tepat dan tindakan pencegahan akan dipatuhi. Modifikasi yang } \\
\text { dilakukan secara mendesak harus dimasukan dalam proses ini. }\end{array}$ \\
\hline 26 & Anti-virus & $\begin{array}{l}\text { Memastikan administrator LAN menginstal anti-virus perangkat lunak standar } \\
\text { perusahaan di semua komputer. Serta adanya pelatihan dan kesadaran teknik } \\
\text { pencegahan virus yang digabungkan dalam program organisasi. }\end{array}$ \\
\hline 27 & Policy & $\begin{array}{l}\text { Mengembangkan kebijakan dan prosedur untuk membatasi akses dan } \\
\text { mengoperasikan hak istimewa bagi mereka yang membutuhkan bisnis. }\end{array}$ \\
\hline 28 & Training & $\begin{array}{l}\text { Pengguna pelatihan akan mencakup instruksi dan dokumentasi tentang } \\
\text { penggunaan aplikasi secara benar. Pentingnya menjaga kerahasiaan dari } \\
\text { account pengguna/rekening pemakai, sandi, dan sifat rahasia dan kompetitif } \\
\text { informasi akan ditekankan. }\end{array}$ \\
\hline 29 & Audit/monitor & $\begin{array}{l}\text { Melaksanakan mekanisme untuk memantau/ mengawasi, melaporkan, dan } \\
\text { kegiatan audit yang diidentifikasi sebagai yang memerlukan tinjauan } \\
\text { independen, termasuk tinjauan berkala user ID untuk memastikan dan } \\
\text { memverifikasi kebutuhan bisnis. }\end{array}$ \\
\hline 30 & Backup & $\begin{array}{l}\text { Kontrol operasi adalah pelatihan untuk cadangan ke sistem administrator akan } \\
\text { disediakan dan tugas diputar diantara mereka untuk memastikan kecukupan/ } \\
\text { kemampuan dari program pelatihan. }\end{array}$ \\
\hline 31 & Training & $\begin{array}{l}\text { Operasi pengendalian: pengembangan aplikasi akan memberikan dokumentasi, } \\
\text { bimbingan, dan dukungan untuk staff operasi dalam melaksanakan mekanisme } \\
\text { untuk memastikan bahwa transfer informasi antara aplikasi aman. }\end{array}$ \\
\hline 32 & Access control & $\begin{array}{l}\text { Operasi kontrol: mekanisme untuk melindungi terhadap resiko database yang } \\
\text { tidak sah, dan modifikasi yang dilakukan dari luar aplikasi, akan ditentukan } \\
\text { dan diimplementasikan. }\end{array}$ \\
\hline 33 & $\begin{array}{l}\text { Interface } \\
\text { dependencies }\end{array}$ & $\begin{array}{l}\text { Operasi kontrol: sistem yang memberikan informasi akan diidentifikasi dan } \\
\text { dikomunikasikan ke penyedia layanan untuk menekankan dampak terhadap } \\
\text { fungsi jika bagian aplikasi ti tidak berada di tempat. }\end{array}$ \\
\hline 34 & Maintenance & $\begin{array}{l}\text { Operasi kontrol: waktu persayaratan untuk pemeliharaan teknis akan dilacak } \\
\text { dan permintaan untuk penyesuaian akan dikomunikasikan kepada manajemen. }\end{array}$ \\
\hline 35 & Training & $\begin{array}{l}\text { Kontrol Pengguna: melaksanakan program pengguna (pengguna evaluasi } \\
\text { kinerja) yang dirancang untuk mendorong kepatuhan terhadap kebijakan dan } \\
\text { prosedur untuk memastikan penggunaan aplikasi yang tepat. }\end{array}$ \\
\hline 36 & $\begin{array}{l}\text { Service level } \\
\text { agreement }\end{array}$ & $\begin{array}{l}\text { Perjanjian tingkat memperoleh layanan adalah untuk menetapkan tingkat } \\
\text { harapan pelanggan dan jaminan dari mendukung operasi. }\end{array}$ \\
\hline 37 & Maintenance & $\begin{array}{l}\text { Memperoleh pemeliharaan atau perjanjian penyaluran/ penyedia untuk } \\
\text { memfasilitasi berkelanjutan status operasional aplikasi. }\end{array}$ \\
\hline 38 & Physical security & $\begin{array}{l}\text { Dalam konsultasi dengan manajemen fasilitas, memfasilitasi pelaksanaan } \\
\text { kontrol keamanan fisik yang dirancang untuk melindungi informasi, perangkat } \\
\text { lunak dan perangkat keras yang membutuhkan sistem. }\end{array}$ \\
\hline 39 & Management support & $\begin{array}{l}\text { Permintaan dukungan manajemen untuk menjamin kerjasama dan koordinasii } \\
\text { berbagai unit bisnis, untuk memfasilitasi kelancaran transisi ke aplikasi. }\end{array}$ \\
\hline 40 & Proprietary & Kepemilikan kontrol. \\
\hline 41 & Corrective strategies & $\begin{array}{l}\text { Tim pengembang akan mengembangkan strategi korektif seperti proses ulang, } \\
\text { merevisi/ merubah logika aplikasi, dll. }\end{array}$ \\
\hline
\end{tabular}




\begin{tabular}{cll}
\hline 42 & Change management & $\begin{array}{l}\text { Produksi kontrol migrasi seperti pencarian dan menghapus/ menghilangkan } \\
\text { proses untuk memastikan penyimpanan data yang bersih. }\end{array}$ \\
\hline 43 & Monitoring & $\begin{array}{l}\text { Melakukan pemerikasaan secara rutin (berkala) terhadap hardware, software, } \\
\text { dan sistem informasi yang ada. }\end{array}$ \\
\hline
\end{tabular}

Tabel 3

Prioritasi Resiko

\begin{tabular}{|c|c|c|c|c|}
\hline No. & Resiko & Tipe & Prioritas & Kontrol \\
\hline 1 & Informasi diakses oleh pihak yang tidak berwenang & INT & $\mathrm{C}$ & $18,20,21,27,40$ \\
\hline 2 & $\begin{array}{l}\text { Kurangnya proses internal untuk membuat dan } \\
\text { mengendalikan, mengelola data di seluruh fungsi }\end{array}$ & INT & $\mathrm{C}$ & $29,32,36$ \\
\hline 3 & Informasi digunakan dalam konteks yang tidak sesuai & INT & $\mathrm{C}$ & $1,2,40$ \\
\hline 4 & $\begin{array}{l}\text { Data diperbarui secara internal tapi tidak dibuat } \\
\text { eksternal }\end{array}$ & INT & $\mathrm{C}$ & $3,25,43$ \\
\hline 5 & $\begin{array}{l}\text { Informasi pihak ketiga dapat menyebabkan masalah } \\
\text { kepada perusahaan }\end{array}$ & INT & $\mathrm{C}$ & $4,25,27$ \\
\hline 6 & Otorisasi keaslian permintaan data & INT & B & $21,22,26$ \\
\hline 7 & $\begin{array}{l}\text { Penolakan akses ke informasi padahal diakses oleh } \\
\text { orang yang berwenang }\end{array}$ & INT & $\mathrm{C}$ & $5,18,25,27$ \\
\hline 8 & $\begin{array}{l}\text { Penggunaan informasi yang tidak benar yang dapat } \\
\text { berdampak pada bisnis }\end{array}$ & INT & $\mathrm{C}$ & $17,24,27,28,30,31,41$ \\
\hline 9 & Prosedur otorisasi pada perusahaan & INT & B & $18,21,34,38,40,43$ \\
\hline 10 & Proses kontrol yang terlalu rumit & INT & $\mathrm{C}$ & 31,35 \\
\hline 11 & Kurangnya personil dibidang sistem aplikasi & INT & $\mathrm{C}$ & $26,27,28,34$ \\
\hline 12 & Informasi dikeluarkan tanpa otorisasi yang tepat & INT & $\mathrm{C}$ & $26,27,28,34,39,43$ \\
\hline 13 & Kebocoran informasi internal perusahaan & INT & $\mathrm{C}$ & $2,4,19,20,21,38,43$ \\
\hline 14 & Tidak menanggapi permintaan secara tepat waktu & INT & $\mathrm{C}$ & $28,34,36$ \\
\hline 15 & $\begin{array}{l}\text { Personil internal sengaja memodifikasi data untuk } \\
\text { pribadi/keuntungan kelompok }\end{array}$ & INT & $\mathrm{C}$ & $2,6,25$ \\
\hline 16 & $\begin{array}{l}\text { Tidak adanya kepercayaan bisnis dengan mitra pihak } \\
\text { ketiga }\end{array}$ & INT & $\mathrm{C}$ & $27,36,38$ \\
\hline 17 & $\begin{array}{l}\text { Tidak adanya rekaman terhadap perubahan } \\
\text { sistem/aplikasi software }\end{array}$ & INT & $\mathrm{C}$ & $18,25,43$ \\
\hline 18 & Data lama/dokumen tidak dihapus & $\begin{array}{l}\text { INT } \\
\end{array}$ & $\mathrm{C}$ & $24,41,43$ \\
\hline 19 & Modifikasi anti virus terhadap perkembangan virus & INT & $\mathrm{C}$ & $17,25,26,27,28,43$ \\
\hline 20 & $\begin{array}{llll}\begin{array}{l}\text { Kesalahan terhadap } \\
\text { dipublikasikan }\end{array} & \text { data/ } & \text { dokumen } & \text { yang } \\
\end{array}$ & INT & $\mathrm{C}$ & $22,23,24,41$ \\
\hline 21 & Informasi dari mitra atau pemasok terjadi kesalahan & INT & C & $22,27,28,32,37$ \\
\hline 22 & Informasi/ data tidak benar & $\mathrm{CON}$ & $\mathrm{C}$ & $26,27,28,43$ \\
\hline 23 & Salah pengelompokan informasi/data & $\mathrm{CON}$ & $\mathrm{C}$ & 7,25 \\
\hline
\end{tabular}




\begin{tabular}{|c|c|c|c|c|}
\hline 24 & $\begin{array}{l}\text { Akses terhadap pelanggan/mitra kerja tidak tersedia } \\
\text { secara lengkap }\end{array}$ & CON & $\mathrm{D}$ & 8,25 \\
\hline 25 & $\begin{array}{l}\text { Mantan user/ karyawan masih memiliki akses untuk } \\
\text { mengamankan data }\end{array}$ & CON & C & 9,25 \\
\hline 26 & $\begin{array}{l}\text { Menggunakan sistem yang rentan untuk mengirim } \\
\text { data/ informasi yang penting }\end{array}$ & CON & $\mathrm{D}$ & $10,25,43$ \\
\hline 27 & $\begin{array}{l}\text { Akses yang tidak terkendali terhadap informasi yang } \\
\text { rahasia }\end{array}$ & CON & $\mathrm{D}$ & $19,21,22,37$ \\
\hline 28 & Informasi sensitif dan tidak sensitif menjadi satu & CON & $\mathrm{D}$ & $22,23,26,27,30$ \\
\hline 29 & 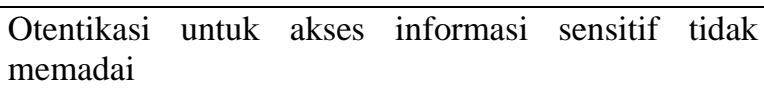 & CON & $\mathrm{D}$ & $10,34,38,43$ \\
\hline 30 & Penyalahgunaan user id & CON & $\mathrm{C}$ & 12,25 \\
\hline 31 & Akses untuk backup data tidak terkontrol dengan baik & CON & $\mathrm{D}$ & $13,25,42,43$ \\
\hline 32 & Keamanan firewall diintrusi & CON & $\mathrm{D}$ & $17,18,38,43$ \\
\hline 33 & $\begin{array}{l}\text { Pihak ketiga membatalkan perjanjian yang telah } \\
\text { dibuat }\end{array}$ & CON & C & $8,20,27$ \\
\hline 34 & Hacker dapat membuat sistem down & AVA & $\mathrm{C}$ & $\begin{array}{l}\text { 16, 17, } 18,20,21,25,36, \\
37,43\end{array}$ \\
\hline 35 & $\begin{array}{l}\text { Situs hosting tidak memiliki perlindungan fisik } \\
\text { informasi }\end{array}$ & AVA & $\mathrm{C}$ & $11,35,37,43$ \\
\hline 36 & $\begin{array}{l}\text { Hubungan jaringan antar sistem gagal didalam } \\
\text { perusahaan }\end{array}$ & AVA & $\mathrm{C}$ & $14,15,17,43$ \\
\hline 37 & Desain sistem terlalu rumit & AVA & $\mathrm{C}$ & $28,31,33$ \\
\hline 38 & Kesalahan terhadap instalasi software/hardware & AVA & $\mathrm{C}$ & $23,24,43$ \\
\hline 39 & Kebutuhan backup tidak memadai & AVA & $\mathrm{D}$ & 13,34 \\
\hline 40 & Kesalahan konfigurasi hardware & AVA & $\mathrm{D}$ & $16,17,18,34$ \\
\hline 41 & Kurangnya pelatihan bagi user & AVA & $\mathrm{C}$ & 27,30 \\
\hline 42 & $\begin{array}{l}\text { Terdapatanya virus dapat menyebabkan kegagalan } \\
\text { sistem/ hilangnya data }\end{array}$ & AVA & $\mathrm{C}$ & $16,17,25$ \\
\hline 43 & $\begin{array}{l}\text { Router yang tidak berfungsi dengan baik dapat } \\
\text { menyebabkan sulitnya akses pada layanan }\end{array}$ & AVA & $\mathrm{C}$ & $33,35,37$ \\
\hline 44 & Ketidaktersediaan dokumen DRP dalam perusahaan & AVA & $\mathrm{C}$ & $13,18,19$ \\
\hline 45 & $\begin{array}{l}\text { Tidak adanya Emergency Respon Procedure yang } \\
\text { diimplementasikan di perusahaan }\end{array}$ & AVA & C & $8,17,18$ \\
\hline
\end{tabular}

Gambar 3 berikut ini merupakan priority risk matrix.

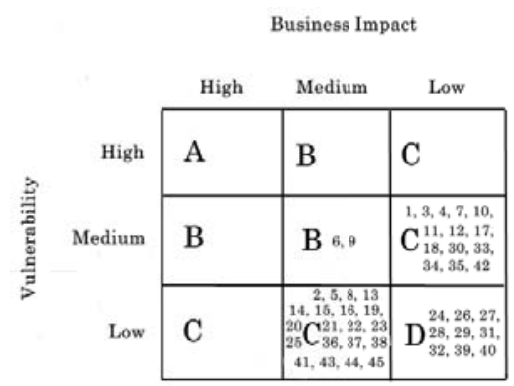

Gambar 3. Priority risk matrix: penyebaran suggested risks. 


\section{Post-FRAP Meeting}

\section{Control/Risks Cross-Reference List}

Control/Risks Cross-reference List bertujuan untuk menentukan control mana yang dapat memitigasi resiko-resiko. Dalam Control/Risks Cross-reference List (Tabel 4) ini kita dapat melihat satu control dapat memitigasi lebih dari satu resiko sehingga dapat membantu dalam menentukan sumber daya mana yang paling baik untuk menangani resiko tersebut. Pimpinan proyek dan fasilitator akan melihat kontrol mana saja yang sudah berada tepat di tempatnya (resiko). Kemudian tim membuat rencana aksi yang berisikan kontrol mana yang akan dilaksanakan, berikut disertai dengan tanggal pelaksanaan atau implementasi kontrol beserta dengan pihak mana yang akan melakukan implementasi kontrol tersebut.

Tabel 4

Control/Risks Cross-Reference List

\begin{tabular}{clccccc}
\hline No. & \multicolumn{1}{c}{ Deskripsi Kontrol } & Resiko & Deskripsi Resiko & Tipe & Prioritas \\
\hline 1 & $\begin{array}{l}\text { Terdapat suatu proses bisnis yang } \\
\text { lengkap sehingga memungkinkan bagi } \\
\text { perusahaan melihat gambaran secara } \\
\text { jelas proses bisnis yang akan dijalankan. }\end{array}$ & & $\begin{array}{l}\text { Informasi digunakan dalam } \\
\text { konteks yang tidak sesuai }\end{array}$ & & C \\
& $\begin{array}{l}\text { INT } \\
\text { Penggunaan informasi dalam perusahaan }\end{array}$ & 3 & Informasi digunakan dalam INT & C \\
& $\begin{array}{l}\text { dipakai dengan cara yang tepat karena } \\
\text { setiap tindakan yang dilakukan } \\
\text { berdasarkan arahan dari yang berwenang } \\
\text { dan tanpa adanya pemalsuan informasi } \\
\text { (otorisasi yang tepat) }\end{array}$
\end{tabular}

\begin{tabular}{|c|c|c|c|c|c|}
\hline & & 13 & $\begin{array}{l}\text { Kebocoran informasi internal } \\
\text { perusahaan }\end{array}$ & INT & $\mathrm{C}$ \\
\hline & & 15 & $\begin{array}{l}\text { Personil internal sengaja } \\
\text { memodifikasi data untuk } \\
\text { pribadi/keuntungan } \\
\text { kelompok }\end{array}$ & INT & C \\
\hline 3 & $\begin{array}{l}\text { Data dalam perusahaan (internal) selalu } \\
\text { di perbarui secara berkala. }\end{array}$ & 4 & $\begin{array}{l}\text { Data diperbarui } \\
\text { internal tapi tidak } \\
\text { eksternal }\end{array}$ & INT & C \\
\hline \multirow[t]{2}{*}{4} & $\begin{array}{l}\text { Adanya sistem keamanan dalam sistem } \\
\text { informasi sehingga tidak sembarang } \\
\text { orang dapat mengakses langsung dalam } \\
\text { sistem (khususnya orang dari pihak luar). }\end{array}$ & 5 & $\begin{array}{l}\text { Informasi pihak ketiga dapat } \\
\text { menyebabkan } \quad \text { masalah } \\
\text { kepada perusahaan }\end{array}$ & INT & $\mathrm{C}$ \\
\hline & & 13 & $\begin{array}{l}\text { Kebocoran informasi internal } \\
\text { perusahaan }\end{array}$ & INT & $\mathrm{C}$ \\
\hline 5 & $\begin{array}{l}\text { Setiap akses yang diberikan kepada } \\
\text { karyawan perusahaan melalui ijin dari } \\
\text { atasan, dan selalu dikonfirmasi dengan } \\
\text { baik kepada pengguna. }\end{array}$ & 7 & 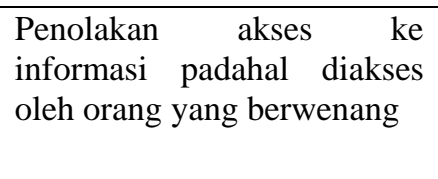 & INT & $\mathrm{C}$ \\
\hline 6 & $\begin{array}{l}\text { Dalam mengupdate/memodifikasi data } \\
\text { diperlukan surat perintah dari atasan, } \\
\text { tidak boleh sembarang merubah, } \\
\text { menambah, ataupun menghilangkan data. }\end{array}$ & 15 & $\begin{array}{l}\text { Personil internal sengaja } \\
\text { memodifikasi data untuk } \\
\text { pribadi/keuntungan } \\
\text { kelompok }\end{array}$ & INT & $\mathrm{C}$ \\
\hline
\end{tabular}




\begin{tabular}{|c|c|c|c|c|c|}
\hline 7 & $\begin{array}{l}\text { Setiap data memiliki pengelompokannya } \\
\text { masing-masing, dan secara teratur } \\
\text { dikordinasi oleh pihak TI. }\end{array}$ & 23 & $\begin{array}{l}\text { Salah pengelompokan } \\
\text { informasi/data }\end{array}$ & $\mathrm{CON}$ & $\mathrm{C}$ \\
\hline \multirow[t]{3}{*}{8} & $\begin{array}{l}\text { Adanya komunikasi yang jelas dengan } \\
\text { mitra kerja/pihak ketiga. }\end{array}$ & 24 & $\begin{array}{l}\text { Akses } \\
\text { pelanggan/mitra kerja tidak } \\
\text { tersedia secara lengkap }\end{array}$ & $\mathrm{CON}$ & $\mathrm{D}$ \\
\hline & & 33 & $\begin{array}{l}\text { Pihak ketiga membatalkan } \\
\text { perjanjian yang telah dibuat }\end{array}$ & $\mathrm{CON}$ & $\mathrm{C}$ \\
\hline & & 45 & $\begin{array}{lr}\text { Tidak adanya } & \text { Emergency } \\
\text { Respon Prosedur yang } \\
\text { diimplementasikan } \\
\text { perusahaan }\end{array}$ & AVA & $\mathrm{C}$ \\
\hline 9 & $\begin{array}{l}\text { Setiap pengguna yang telah keluar } \\
\text { perusahaan (resign), akan langsung } \\
\text { dicabut aksesnya terhadap akses sistem } \\
\text { informasi. }\end{array}$ & 25 & $\begin{array}{l}\text { Mantan user/ karyawan } \\
\text { masih memiliki akses untuk } \\
\text { mengamankan data }\end{array}$ & $\mathrm{CON}$ & $\mathrm{C}$ \\
\hline \multirow[t]{2}{*}{10} & $\begin{array}{l}\text { Sistem penyaluran informasi/akses dalam } \\
\text { perusahaan memiliki kualitas yang baik } \\
\text { dan terjaga kerahasiaannya. }\end{array}$ & 26 & $\begin{array}{l}\text { Menggunakan sistem yang } \\
\text { rentan untuk mengirim data/ } \\
\text { informasi yang penting }\end{array}$ & $\mathrm{CON}$ & $\mathrm{D}$ \\
\hline & & 29 & $\begin{array}{lcc}\text { Otentikasi } & \text { untuk } & \text { akses } \\
\text { informasi } & \text { sensitif } & \text { tidak } \\
\text { memadai } & & \\
\end{array}$ & $\mathrm{CON}$ & $\mathrm{D}$ \\
\hline 11 & $\begin{array}{l}\text { Setiap Laptop dan Personal Komputer } \\
\text { harus memiliki perlindungan Firewall } \\
\text { dan Antivirus yang sesuai standar } \\
\text { perusahaan. }\end{array}$ & 35 & $\begin{array}{l}\text { Situs hosting tidak memiliki } \\
\text { perlindungan fisik informasi }\end{array}$ & AVA & $\mathrm{C}$ \\
\hline 12 & Setiap pengguna memiliki satu ID user. & 30 & Penyalahgunaan user ID & $\mathrm{CON}$ & $\mathrm{C}$ \\
\hline \multirow[t]{3}{*}{13} & $\begin{array}{l}\text { Rencana pemulihan dari kemungkinan } \\
\text { kerusakan-kerusakan yang berdampak } \\
\text { pada kemampuan proses komputer dan } \\
\text { operasi bisnis perusahaan. }\end{array}$ & 31 & $\begin{array}{l}\text { Akses untuk backup data } \\
\text { tidak terkontrol dengan baik }\end{array}$ & $\mathrm{CON}$ & $\mathrm{D}$ \\
\hline & & 39 & $\begin{array}{l}\text { Kebutuhan backup tidak } \\
\text { memadai }\end{array}$ & AVA & $\mathrm{D}$ \\
\hline & & 44 & $\begin{array}{l}\text { Ketidaktersediaan dokumen } \\
\text { DRP dalam perusahaan }\end{array}$ & AVA & $\mathrm{C}$ \\
\hline 14 & $\begin{array}{l}\text { Perusahaan memiliki server yang baik } \\
\text { dan memadai. }\end{array}$ & 36 & $\begin{array}{l}\text { Hubungan jaringan antar } \\
\text { sistem gagal didalam } \\
\text { perusahaan }\end{array}$ & AVA & $\mathrm{C}$ \\
\hline 15 & $\begin{array}{l}\text { Perusahaan memiliki mitra bisnis yang } \\
\text { baik dan memadai. }\end{array}$ & 36 & $\begin{array}{l}\text { Hubungan jaringan antar } \\
\text { sistem gagal didalam } \\
\text { perusahaan }\end{array}$ & AVA & C \\
\hline \multirow[t]{3}{*}{16} & $\begin{array}{l}\text { Perusahaan mengikuti perkembangan } \\
\text { zaman terhadap OS komputer. }\end{array}$ & 34 & $\begin{array}{l}\text { Hacker dapat membuat } \\
\text { sistem down }\end{array}$ & AVA & $\mathrm{C}$ \\
\hline & & 40 & $\begin{array}{l}\text { Konfigurasi hardware yang } \\
\text { tidak memadai }\end{array}$ & AVA & $\mathrm{D}$ \\
\hline & & 42 & $\begin{array}{l}\text { Terdapatanya virus dapat } \\
\text { menyebabkan kegagalan } \\
\text { sistem/hilangnya data }\end{array}$ & AVA & $\mathrm{C}$ \\
\hline
\end{tabular}




\begin{tabular}{|c|c|c|c|c|c|}
\hline \multirow[t]{8}{*}{17} & \multirow[t]{8}{*}{$\begin{array}{l}\text { Persyaratan cadangan akan ditentukan } \\
\text { dan dikomunikasikan ke penyedia } \\
\text { layanan, termasuk permintaan bahwa } \\
\text { pemberitahuan elektronik dimana } \\
\text { cadangan diselesaikan, dikirim ke } \\
\text { administrator sistem aplikasi. } \\
\text { Operasional akan diminta untuk menguji } \\
\text { prosedur cadangan. }\end{array}$} & 8 & $\begin{array}{l}\text { Penggunaan informasi yang } \\
\text { tidak benar yang dapat } \\
\text { berdampak pada bisnis }\end{array}$ & INT & $\mathrm{C}$ \\
\hline & & 19 & $\begin{array}{lcr}\text { Modifikasi } & \text { anti } & \text { virus } \\
\text { terhadap } & \text { perkembangan } \\
\text { virus } & \\
\end{array}$ & INT & $\mathrm{C}$ \\
\hline & & 32 & Keamanan firewall diintrusi & $\mathrm{CON}$ & $\mathrm{D}$ \\
\hline & & 34 & $\begin{array}{l}\text { Hacker dapat membuat } \\
\text { sistem down }\end{array}$ & AVA & $\mathrm{C}$ \\
\hline & & 36 & $\begin{array}{l}\text { Hubungan jaringan antar } \\
\text { sistem gagal didalam } \\
\text { perusahaan }\end{array}$ & AVA & $\mathrm{C}$ \\
\hline & & 40 & $\begin{array}{l}\text { Kesalahan } \\
\text { hardware }\end{array}$ & AVA & $\mathrm{C}$ \\
\hline & & 42 & $\begin{array}{l}\text { Terdapatanya virus dapat } \\
\text { menyebabkan kegagalan } \\
\text { sistem/ hilangnya data }\end{array}$ & AVA & $\mathrm{C}$ \\
\hline & & 45 & $\begin{array}{lr}\text { Tidak adanya Emergency } \\
\text { Respon Procedure yang } \\
\text { diimplementasikan } \\
\text { perusahaan }\end{array}$ & AVA & $\mathrm{C}$ \\
\hline \multirow[t]{9}{*}{18} & $\begin{array}{l}\text { Mengembangkan, mendokumentasikan, } \\
\text { dan menguji prosedur pemulihan yang } \\
\text { dirancang untuk merancang untuk } \\
\text { memastikan bahwa aplikasi dan } \\
\text { informasi dapat diperoleh kembali, } \\
\text { dengan menggunakan cadangan yang } \\
\text { dibuat, jika terjadinya kemungkinan } \\
\text { kehilangan data. }\end{array}$ & 1 & $\begin{array}{l}\text { Informasi diakses oleh pihak } \\
\text { yang tidak berwenang }\end{array}$ & INT & $\mathrm{C}$ \\
\hline & & 7 & $\begin{array}{l}\text { Penolakan akses ke } \\
\text { informasi padahal diakses } \\
\text { oleh orang yang berwenang }\end{array}$ & INT & $\mathrm{C}$ \\
\hline & & 9 & $\begin{array}{lll}\begin{array}{l}\text { Prosedur otorisasi } \\
\text { perusahaan }\end{array} & \text { pada } \\
\end{array}$ & INT & B \\
\hline & & 17 & $\begin{array}{l}\text { Tidak adanya rekaman } \\
\text { terhadap } \\
\text { sistem/aplikasi software } \\
\end{array}$ & INT & $\mathrm{C}$ \\
\hline & & 32 & Keamanan firewall diintrusi & $\mathrm{CON}$ & $\mathrm{D}$ \\
\hline & & 34 & $\begin{array}{l}\text { Hacker dapat membuat } \\
\text { sistem down }\end{array}$ & $\mathrm{AVA}$ & $\mathrm{C}$ \\
\hline & & 40 & $\begin{array}{l}\text { Konfigurasi hardware yang } \\
\text { tidak memadai }\end{array}$ & AVA & $\mathrm{D}$ \\
\hline & & 44 & $\begin{array}{l}\text { Ketidaktersediaan dokumen } \\
\text { DRP dalam perusahaan }\end{array}$ & AVA & $\mathrm{C}$ \\
\hline & & 45 & $\begin{array}{lr}\text { Tidak adanya Emergency } \\
\text { Response Procedure yang } \\
\text { diimplementasikan } \\
\text { perusahaan }\end{array}$ & AVA & $\mathrm{C}$ \\
\hline
\end{tabular}




\begin{tabular}{|c|c|c|c|c|c|}
\hline 19 & $\begin{array}{l}\text { Menerapkan mekanisme kontrol akses } \\
\text { untuk mencegah akses yang tidak sah } \\
\text { terhadap informasi. Mekanisme ini akan } \\
\text { mencakup kemampuan untuk } \\
\text { mendeteksi, dan melaporkan pencobaan } \\
\text { terhadap keamanan informasi. }\end{array}$ & 13 & $\begin{array}{l}\text { Kebocoran informasi internal } \\
\text { perusahaan }\end{array}$ & INT & $\mathrm{C}$ \\
\hline & & 27 & $\begin{array}{l}\text { Akses yang tidak terkendali } \\
\text { terhadap informasi yang } \\
\text { rahasia }\end{array}$ & $\mathrm{CON}$ & D \\
\hline & & 44 & $\begin{array}{l}\text { Ketidaktersediaan dokumen } \\
\text { DRP dalam perusahaan }\end{array}$ & AVA & $\mathrm{C}$ \\
\hline \multirow[t]{4}{*}{20} & $\begin{array}{l}\text { Sumber akses adalah menerapkan } \\
\text { mekanisme untuk membatasi akses ke } \\
\text { informasi rahasia dan ke jalur jaringan } \\
\text { tertentu atau lokasi fisik. }\end{array}$ & 1 & $\begin{array}{l}\text { Informasi diakses oleh pihak } \\
\text { yang tidak berwenang }\end{array}$ & INT & $\mathrm{C}$ \\
\hline & & 13 & $\begin{array}{l}\text { Kebocoran informasi internal } \\
\text { perusahaan }\end{array}$ & INT & $\mathrm{C}$ \\
\hline & & 33 & $\begin{array}{l}\text { Pihak ketiga membatalkan } \\
\text { perjanjian yang telah dibuat }\end{array}$ & $\mathrm{CON}$ & $\mathrm{C}$ \\
\hline & & 34 & $\begin{array}{l}\text { Hacker dapat membuat } \\
\text { sistem down }\end{array}$ & AVA & $\mathrm{C}$ \\
\hline \multirow[t]{6}{*}{21} & $\begin{array}{l}\text { Melaksanakan mekanisme otentikasi } \\
\text { pengguna (seperti firewall, tombol/dial-in } \\
\text { kontrol, keamanan ID) untuk membatasi } \\
\text { akses ke petugas yang berwenang. }\end{array}$ & 1 & $\begin{array}{l}\text { Informasi diakses oleh pihak } \\
\text { yang tidak berwenang }\end{array}$ & INT & $\mathrm{C}$ \\
\hline & & 6 & $\begin{array}{ll}\text { Otorisasi } & \text { keaslian } \\
\text { permintaan data } & \\
\end{array}$ & INT & B \\
\hline & & 9 & $\begin{array}{lll}\begin{array}{l}\text { Prosedur } \\
\text { perusahaan }\end{array} & \text { otorisasi } & \text { pada } \\
\end{array}$ & INT & B \\
\hline & & 13 & $\begin{array}{l}\text { Kebocoran informasi internal } \\
\text { perusahaan }\end{array}$ & INT & $\mathrm{C}$ \\
\hline & & 27 & $\begin{array}{l}\text { Akses yang tidak terkendali } \\
\text { terhadap informasi yang } \\
\text { rahasia }\end{array}$ & $\mathrm{CON}$ & $\mathrm{D}$ \\
\hline & & 34 & $\begin{array}{l}\text { Hacker dapat membuat } \\
\text { sistem down }\end{array}$ & AVA & $\mathrm{C}$ \\
\hline \multirow[t]{5}{*}{22} & $\begin{array}{l}\text { Melaksanakan mekanisme enkripsi (data, } \\
\text { end-to-end) untuk mencegah akses yang } \\
\text { tidak sah untuk melindungi integritas } \\
\text { sebuah kerahasiaan informasi. }\end{array}$ & 6 & $\begin{array}{ll}\text { Otorisasi } & \text { keaslian } \\
\text { permintaan data }\end{array}$ & INT & B \\
\hline & & 20 & $\begin{array}{ll}\begin{array}{l}\text { Kesalahan terhadap } \\
\text { dokumen } \\
\text { dipublikasikan }\end{array} & \text { yang } \\
\end{array}$ & INT & $\mathrm{C}$ \\
\hline & & 21 & $\begin{array}{l}\text { Informasi dari mitra atau } \\
\text { pemasok terjadi kesalahan }\end{array}$ & INT & $\mathrm{C}$ \\
\hline & & 27 & $\begin{array}{l}\text { Akses yang tidak terkendali } \\
\text { terhadap informasi yang } \\
\text { rahasia }\end{array}$ & $\mathrm{CON}$ & $\mathrm{D}$ \\
\hline & & 28 & $\begin{array}{l}\text { Informasi sensitif dan tidak } \\
\text { sensitif menjadi satu }\end{array}$ & $\mathrm{CON}$ & D \\
\hline
\end{tabular}




\begin{tabular}{|c|c|c|c|c|c|}
\hline \multirow[t]{3}{*}{23} & $\begin{array}{lcr}\begin{array}{l}\text { Merancang } \\
\text { pengendalian }\end{array} & \text { daplikasi } & \begin{array}{c}\text { menerapkan } \\
\text { (pengecekan }\end{array} \\
\text { pemasukan data lapangan yang } \\
\text { memerlukan validasi, indikator alarm, } \\
\text { kemampuan } & \text { sandi kadaluarsa, } \\
\text { pengecekan jumlah) untuk menjamin } & \\
\text { integritas, kerahasiaan, dan ketersediaan } \\
\text { informasi aplikasi. }\end{array}$ & 20 & $\begin{array}{ll}\text { Kesalahan terhadap } & \text { data/ } \\
\text { dokumen } & \text { yang } \\
\text { dipublikasikan } & \end{array}$ & INT & $\mathrm{C}$ \\
\hline & & 28 & $\begin{array}{l}\text { Informasi sensitif dan tidak } \\
\text { sensitif menjadi satu }\end{array}$ & $\mathrm{CON}$ & $\mathrm{D}$ \\
\hline & & 38 & $\begin{array}{l}\text { Kesalahan terhadap instalasi } \\
\text { software/hardware }\end{array}$ & AVA & $\mathrm{C}$ \\
\hline \multirow[t]{3}{*}{24} & $\begin{array}{l}\text { Mengembangkan prosedur pengujian } \\
\text { yang harus diikuti selama aplikasi dan } \\
\text { selama modifikasi aplikasi yang sudah } \\
\text { ada yang mencakup penggunaan } \\
\text { partisipasi dan penerimaan. }\end{array}$ & 8 & $\begin{array}{l}\text { Penggunaan informasi yang } \\
\text { tidak benar yang dapat } \\
\text { berdampak pada bisnis }\end{array}$ & INT & $\mathrm{C}$ \\
\hline & & 18 & $\begin{array}{l}\text { Data lama/dokumen tidak } \\
\text { dihapus }\end{array}$ & INT & $\mathrm{C}$ \\
\hline & & 38 & $\begin{array}{l}\text { Kesalahan terhadap instalasi } \\
\text { software/hardware }\end{array}$ & AVA & C \\
\hline \multirow[t]{9}{*}{25} & $\begin{array}{l}\text { Mematuhi suatu proses perubahan } \\
\text { manajemen yang dirancang untuk } \\
\text { memfasilitasikan pendekatan struktur } \\
\text { untuk modifikasi, untuk memastikan } \\
\text { langkah yang tepat dan tindakan } \\
\text { pencegahan akan dipatuhi. Modifikasi } \\
\text { yang dilakukan secara mendesak harus } \\
\text { dimasukan dalam proses ini. }\end{array}$ & 4 & $\begin{array}{lll}\text { Data diperbarui } & \text { secara } \\
\text { internal tapi tidak } & \text { dibuat } \\
\text { eksternal } & & \\
\text { nat }\end{array}$ & INT & C \\
\hline & & 5 & $\begin{array}{l}\text { Informasi pihak ketiga dapat } \\
\text { menyebabkan masalah } \\
\text { kepada perusahaan }\end{array}$ & INT & C \\
\hline & & 7 & 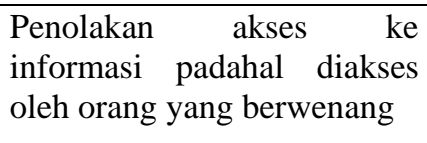 & INT & C \\
\hline & & 15 & $\begin{array}{l}\text { Personil internal sengaja } \\
\text { memodifikasi data untuk } \\
\text { pribadi/keuntungan } \\
\text { kelompok }\end{array}$ & INT & C \\
\hline & & 17 & $\begin{array}{l}\text { Tidak adanya rekaman } \\
\text { terhadap perubahan } \\
\text { sistem/aplikasi software }\end{array}$ & INT & $\mathrm{C}$ \\
\hline & & 19 & $\begin{array}{lcr}\begin{array}{l}\text { Modifikasi } \\
\text { terhadap }\end{array} & \text { anti virus } \\
\text { virus } & \text { perkembangan } \\
\end{array}$ & INT & C \\
\hline & & 23 & $\begin{array}{l}\text { Salah pengelompokan } \\
\text { informasi/data }\end{array}$ & $\mathrm{CON}$ & C \\
\hline & & 24 & $\begin{array}{l}\text { Akses terhadap } \\
\text { pelanggan/mitra kerja tidak } \\
\text { tersedia secara lengkap }\end{array}$ & $\mathrm{CON}$ & $\mathrm{D}$ \\
\hline & & 25 & $\begin{array}{l}\text { Mantan user/ karyawan } \\
\text { masih memiliki akses untuk } \\
\text { mengamankan data }\end{array}$ & $\mathrm{CON}$ & $\mathrm{C}$ \\
\hline
\end{tabular}




\begin{tabular}{|c|c|c|c|c|c|}
\hline & & 26 & $\begin{array}{l}\text { Menggunakan sistem yang } \\
\text { rentan untuk mengirim data/ } \\
\text { informasi yang penting }\end{array}$ & CON & $\mathrm{D}$ \\
\hline & & 30 & Penyalahgunaan user ID & $\mathrm{CON}$ & $\mathrm{C}$ \\
\hline & & 31 & $\begin{array}{l}\text { Akses untuk backup data } \\
\text { tidak terkontrol dengan baik }\end{array}$ & CON & $\mathrm{D}$ \\
\hline & & 34 & $\begin{array}{l}\text { Hacker dapat membuat } \\
\text { sistem down }\end{array}$ & AVA & $\mathrm{C}$ \\
\hline & & 42 & $\begin{array}{l}\text { Terdapatanya virus dapat } \\
\text { menyebabkan } \quad \text { kegagalan } \\
\text { sistem/ hilangnya data }\end{array}$ & AVA & $\mathrm{C}$ \\
\hline 26 & $\begin{array}{l}\text { Memastikan administrator } \\
\text { menginstal anti-virus perangkat lunak } \\
\text { standar perusahaan di semua komputer. } \\
\text { Serta adanya pelatihan dan kesadaran } \\
\text { teknik pencegahan virus yang } \\
\text { digabungkan dalam program organisasi. }\end{array}$ & 6 & $\begin{array}{ll}\text { Otorisasi } & \text { keaslian } \\
\text { permintaan data } & \end{array}$ & INT & $\mathrm{B}$ \\
\hline & & 11 & $\begin{array}{l}\text { Kurangnya personil dibidang } \\
\text { sistem aplikasi }\end{array}$ & INT & $\mathrm{C}$ \\
\hline & & 12 & $\begin{array}{l}\text { Informasi dikeluarkan tanpa } \\
\text { otorisasi yang tepat }\end{array}$ & INT & $\mathrm{C}$ \\
\hline & & 19 & 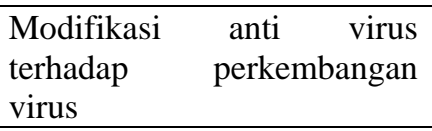 & INT & $\mathrm{C}$ \\
\hline & & 22 & Informasi/ data tidak benar & $\mathrm{CON}$ & $\mathrm{C}$ \\
\hline & & 28 & $\begin{array}{l}\text { Informasi sensitif dan tidak } \\
\text { sensitif menjadi satu }\end{array}$ & $\mathrm{CON}$ & $\mathrm{D}$ \\
\hline 27 & $\begin{array}{l}\text { Mengembangkan kebijakan dan prosedur } \\
\text { untuk membatasi akses dan } \\
\text { mengoperasikan hak istimewa bagi } \\
\text { mereka yang membutuhkan bisnis. }\end{array}$ & 1 & $\begin{array}{l}\text { Informasi diakses oleh pihak } \\
\text { yang tidak berwenang }\end{array}$ & INT & $\mathrm{C}$ \\
\hline & & 5 & $\begin{array}{l}\text { Informasi pihak ketiga dapat } \\
\text { menyebabkan } \quad \text { masalah } \\
\text { kepada perusahaan }\end{array}$ & INT & $\mathrm{C}$ \\
\hline & & 7 & $\begin{array}{l}\text { Penolakan akses ke } \\
\text { informasi padahal diakses } \\
\text { oleh orang yang berwenang }\end{array}$ & INT & $\mathrm{C}$ \\
\hline & & 8 & $\begin{array}{l}\text { Penggunaan informasi yang } \\
\text { tidak benar yang dapat } \\
\text { berdampak pada bisnis }\end{array}$ & INT & $\mathrm{C}$ \\
\hline & & 11 & $\begin{array}{l}\text { Kurangnya personil dibidang } \\
\text { sistem aplikasi }\end{array}$ & INT & $\mathrm{C}$ \\
\hline & & 12 & $\begin{array}{l}\text { Informasi dikeluarkan tanpa } \\
\text { otorisasi yang tepat }\end{array}$ & INT & $\mathrm{C}$ \\
\hline & & 16 & $\begin{array}{l}\text { Tidak adanya kepercayaan } \\
\text { bisnis dengan mitra pihak } \\
\text { ketiga }\end{array}$ & INT & $\mathrm{C}$ \\
\hline & & 19 & $\begin{array}{l}\text { Modifikasi } \\
\begin{array}{l}\text { anti } \\
\text { terhadap }\end{array} \\
\text { virus }\end{array}$ & INT & $\mathrm{C}$ \\
\hline
\end{tabular}




\begin{tabular}{|c|c|c|c|c|c|}
\hline & & 21 & $\begin{array}{l}\text { Informasi dari mitra atau } \\
\text { pemasok terjadi kesalahan }\end{array}$ & INT & $\mathrm{C}$ \\
\hline & & 22 & Informasi/ data tidak benar & $\mathrm{CON}$ & $\mathrm{C}$ \\
\hline & & 28 & $\begin{array}{l}\text { Informasi sensitif dan tidak } \\
\text { sensitif menjadi satu }\end{array}$ & $\mathrm{CON}$ & $\mathrm{D}$ \\
\hline & & 33 & $\begin{array}{l}\text { Pihak ketiga membatalkan } \\
\text { perjanjian yang telah dibuat }\end{array}$ & $\mathrm{CON}$ & $\mathrm{C}$ \\
\hline & & 41 & $\begin{array}{l}\text { Kurangnya pelatihan bagi } \\
\text { user }\end{array}$ & AVA & $\mathrm{C}$ \\
\hline \multirow[t]{8}{*}{28} & $\begin{array}{llr}\text { Pengguna pelatihan akan mencakup } \\
\text { instruksi dan dokumentasi tentang } \\
\text { penggunaan aplikasi secara benar. }\end{array}$ & 8 & $\begin{array}{l}\text { Penggunaan informasi yang } \\
\text { tidak benar yang dapat } \\
\text { berdampak pada bisnis }\end{array}$ & INT & $\mathrm{C}$ \\
\hline & & 11 & $\begin{array}{l}\text { Kurangnya personil dibidang } \\
\text { sistem aplikasi }\end{array}$ & INT & $\mathrm{C}$ \\
\hline & & 12 & $\begin{array}{l}\text { Informasi dikeluarkan tanpa } \\
\text { otorisasi yang tepat }\end{array}$ & INT & $\mathrm{C}$ \\
\hline & & 14 & \begin{tabular}{lr} 
Tidak & \multicolumn{2}{c}{ menanggapi } \\
permintaan & secara tepat \\
waktu &
\end{tabular} & INT & $\mathrm{C}$ \\
\hline & & 19 & 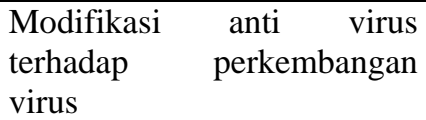 & INT & $\mathrm{C}$ \\
\hline & & 21 & $\begin{array}{l}\text { Informasi dari mitra atau } \\
\text { pemasok terjadi kesalahan }\end{array}$ & INT & $\mathrm{C}$ \\
\hline & & 22 & Informasi/ data tidak benar & $\mathrm{CON}$ & $\mathrm{C}$ \\
\hline & & 37 & Desain sistem terlalu rumit & AVA & $\mathrm{C}$ \\
\hline 29 & $\begin{array}{l}\text { Melaksanakan mekanisme untuk } \\
\text { memantau/ mengawasi, melaporkan, dan } \\
\text { kegiatan audit yang diidentifikasi sebagai } \\
\text { yang memerlukan tinjauan independen, } \\
\text { termasuk tinjauan berkala user ID untuk } \\
\text { memastikan dan memverifikasi } \\
\text { kebutuhan bisnis. }\end{array}$ & 2 & $\begin{array}{l}\text { Kurangnya proses internal } \\
\text { untuk membuat dan } \\
\text { mengendalikan, mengelola } \\
\text { data di seluruh fungsi }\end{array}$ & INT & $\mathrm{C}$ \\
\hline \multirow[t]{3}{*}{30} & $\begin{array}{l}\text { Kontrol operasi adalah pelatihan untuk } \\
\text { cadangan ke sistem administrator akan } \\
\text { disediakan dan tugas diputar diantara } \\
\text { mereka untuk memastikan kecukupan/ } \\
\text { kemampuan dari program pelatihan. }\end{array}$ & 8 & $\begin{array}{l}\text { Penggunaan informasi yang } \\
\text { tidak benar yang dapat } \\
\text { berdampak pada bisnis }\end{array}$ & INT & $\mathrm{C}$ \\
\hline & & 28 & $\begin{array}{l}\text { Informasi sensitif dan tidak } \\
\text { sensitif menjadi satu }\end{array}$ & $\mathrm{CON}$ & $\mathrm{D}$ \\
\hline & & 41 & $\begin{array}{l}\text { Kurangnya pelatihan bagi } \\
\text { user }\end{array}$ & AVA & $\mathrm{C}$ \\
\hline 31 & $\begin{array}{l}\text { Operasi pengendalian: pengembangan } \\
\text { aplikasi akan memberikan dokumentasi, } \\
\text { bimbingan, dan dukungan untuk staff } \\
\text { operasi dalam melaksanakan mekanisme } \\
\text { untuk memastikan bahwa transfer } \\
\text { informasi antara aplikasi aman. }\end{array}$ & 8 & $\begin{array}{l}\text { Penggunaan informasi yang } \\
\text { tidak benar yang dapat } \\
\text { berdampak pada bisnis }\end{array}$ & INT & $\mathrm{C}$ \\
\hline
\end{tabular}




\begin{tabular}{|c|c|c|c|c|c|}
\hline & & 10 & $\begin{array}{l}\text { Proses kontrol yang terlalu } \\
\text { rumit }\end{array}$ & INT & $\mathrm{C}$ \\
\hline & & 37 & Desain sistem terlalu rumit & AVA & $\mathrm{C}$ \\
\hline \multirow[t]{2}{*}{32} & $\begin{array}{l}\text { Operasi Kontrol: Mekanisme untuk } \\
\text { melindungi terhadap resiko database } \\
\text { yang tidak sah, dan modifikasi yang } \\
\text { dilakukan dari luar aplikasi, akan } \\
\text { ditentukan dan diimplementasikan. }\end{array}$ & 2 & $\begin{array}{l}\text { Kurangnya proses internal } \\
\text { untuk membuat dan } \\
\text { mengendalikan, mengelola } \\
\text { data di seluruh fungsi }\end{array}$ & INT & $\mathrm{C}$ \\
\hline & & 21 & $\begin{array}{l}\text { Informasi dari mitra atau } \\
\text { pemasok terjadi kesalahan }\end{array}$ & INT & $\mathrm{C}$ \\
\hline \multirow[t]{2}{*}{33} & $\begin{array}{l}\text { Operasi Kontrol: Sistem yang } \\
\text { memberikan informasi akan diidentifikasi } \\
\text { dan dikomunikasikan ke penyedia } \\
\text { layanan untuk menekankan dampak } \\
\text { terhadap fungsi jika pengisian aplikasi ini } \\
\text { tidak tersedia. }\end{array}$ & 37 & Desain sistem terlalu rumit & AVA & $\mathrm{C}$ \\
\hline & & 43 & $\begin{array}{l}\text { Router yang tidak berfungsi } \\
\text { dengan baik dapat } \\
\text { menyebabkan sulitnya akses } \\
\text { pada layanan }\end{array}$ & AVA & $\mathrm{C}$ \\
\hline \multirow[t]{7}{*}{34} & $\begin{array}{l}\text { Operasi Kontrol: Waktu persayaratan } \\
\text { untuk pemeliharaan teknis akan dilacak } \\
\text { dan permintaan untuk penyesuaian akan } \\
\text { dikomunikasikan kepada manajemen jika } \\
\text { diberikan jaminan. }\end{array}$ & 9 & $\begin{array}{l}\text { Prosedur otorisasi pada } \\
\text { perusahaan }\end{array}$ & INT & B \\
\hline & & 11 & $\begin{array}{l}\text { Kurangnya personil dibidang } \\
\text { sistem aplikasi }\end{array}$ & INT & C \\
\hline & & 12 & $\begin{array}{l}\text { Informasi dikeluarkan tanpa } \\
\text { otorisasi yang tepat }\end{array}$ & INT & $\mathrm{C}$ \\
\hline & & 14 & \begin{tabular}{lr} 
Tidak & \multicolumn{2}{c}{ menanggapi } \\
permintaan & secara tepat \\
waktu & \\
\end{tabular} & INT & $\mathrm{C}$ \\
\hline & & 29 & $\begin{array}{lcc}\text { Otentikasi } & \text { untuk } & \text { akses } \\
\text { informasi } & \text { sensitif } & \text { tidak } \\
\text { memadai } & & \\
\end{array}$ & $\mathrm{CON}$ & $\mathrm{D}$ \\
\hline & & 39 & $\begin{array}{l}\text { Kebutuhan backup tidak } \\
\text { memadai }\end{array}$ & AVA & $\mathrm{D}$ \\
\hline & & 40 & $\begin{array}{l}\text { Konfigurasi hardware yang } \\
\text { tidak memadai }\end{array}$ & AVA & $\mathrm{D}$ \\
\hline \multirow[t]{3}{*}{35} & $\begin{array}{l}\text { Kontrol Pengguna: melaksanakan } \\
\text { program pengguna (pengguna evaluasi } \\
\text { kinerja) yang dirancang untuk } \\
\text { mendorong kepatuhan terhadap kebijakan } \\
\text { dan prosedur untuk memastikan } \\
\text { penggunaan aplikasi yang tepat. }\end{array}$ & 10 & $\begin{array}{l}\text { Proses kontrol yang terlalu } \\
\text { rumit }\end{array}$ & INT & $\mathrm{C}$ \\
\hline & & 35 & $\begin{array}{l}\text { Situs hosting tidak memiliki } \\
\text { perlindungan fisik informasi }\end{array}$ & AVA & $\mathrm{C}$ \\
\hline & & 43 & $\begin{array}{l}\text { Router yang tidak berfungsi } \\
\text { dengan baik dapat } \\
\text { menyebabkan sulitnya akses } \\
\text { pada layanan }\end{array}$ & AVA & $\mathrm{C}$ \\
\hline
\end{tabular}




\begin{tabular}{|c|c|c|c|c|c|}
\hline \multirow[t]{5}{*}{36} & \multirow[t]{5}{*}{$\begin{array}{l}\text { Perjanjian tingkat memperoleh layanan } \\
\text { adalah untuk menetapkan tingkat harapan } \\
\text { pelanggan dan jaminan dari mendukung } \\
\text { operasi. }\end{array}$} & 2 & $\begin{array}{l}\text { Kurangnya proses internal } \\
\text { untuk membuat dan } \\
\text { mengendalikan, mengelola } \\
\text { data di seluruh fungsi }\end{array}$ & \multirow{3}{*}{$\begin{array}{l}\text { INT } \\
\text { INT }\end{array}$} & \multirow{3}{*}{$\begin{array}{l}\mathrm{C} \\
\mathrm{C}\end{array}$} \\
\hline & & 14 & Tidak menanggapi & & \\
\hline & & & $\begin{array}{l}\text { permintaan secara tepat } \\
\text { waktu }\end{array}$ & & \\
\hline & & 16 & $\begin{array}{l}\text { Tidak adanya kepercayaan } \\
\text { bisnis dengan mitra pihak } \\
\text { ketiga }\end{array}$ & INT & $\mathrm{C}$ \\
\hline & & 34 & $\begin{array}{l}\text { Hacker dapat membuat } \\
\text { sistem down }\end{array}$ & AVA & $\mathrm{C}$ \\
\hline \multirow[t]{5}{*}{37} & $\begin{array}{lrr}\text { Memperoleh pemeliharaan } & \text { atau } \\
\text { perjanjian penyaluran/ penyedia } & \text { untuk } \\
\text { memfasilitasi berkelanjutan } & \text { status } \\
\text { operasional aplikasi. } & \end{array}$ & 21 & $\begin{array}{l}\text { Informasi dari mitra atau } \\
\text { pemasok terjadi kesalahan }\end{array}$ & INT & $\mathrm{C}$ \\
\hline & & 27 & $\begin{array}{l}\text { Akses yang tidak terkendali } \\
\text { terhadap informasi yang } \\
\text { rahasia }\end{array}$ & $\mathrm{CON}$ & $\mathrm{D}$ \\
\hline & & 34 & $\begin{array}{l}\text { Hacker dapat membuat } \\
\text { sistem down }\end{array}$ & AVA & $\mathrm{C}$ \\
\hline & & 35 & $\begin{array}{l}\text { Situs hosting tidak memiliki } \\
\text { perlindungan fisik informasi }\end{array}$ & AVA & $\mathrm{C}$ \\
\hline & & 43 & $\begin{array}{l}\text { Router yang tidak berfungsi } \\
\text { dengan baik dapat } \\
\text { menyebabkan sulitnya akses } \\
\text { pada layanan }\end{array}$ & AVA & $\mathrm{C}$ \\
\hline \multirow[t]{5}{*}{38} & $\begin{array}{l}\text { Dalam konsultasi dengan } \\
\text { fasilitas, manajemen } \\
\end{array}$ & 9 & $\begin{array}{lll}\text { Prosedur otorisasi } & \text { pada } \\
\text { perusahaan } & & \end{array}$ & INT & $\mathrm{B}$ \\
\hline & & 13 & $\begin{array}{l}\text { Kebocoran informasi } \\
\text { internal perusahaan }\end{array}$ & INT & $\mathrm{C}$ \\
\hline & & 16 & $\begin{array}{ll}\text { Tidak adanya kepercayaan } \\
\text { bisnis dengan mitra pihak } \\
\text { ketiga }\end{array}$ & INT & $\mathrm{C}$ \\
\hline & & 29 & $\begin{array}{lcc}\text { Otentikasi } & \text { untuk } & \text { akses } \\
\text { informasi } & \text { sensitif } & \text { tidak } \\
\text { memadai } & & \\
\end{array}$ & $\mathrm{CON}$ & $\mathrm{D}$ \\
\hline & & 32 & Keamanan firewall diintrusi & $\mathrm{CON}$ & $\mathrm{D}$ \\
\hline 39 & $\begin{array}{l}\text { Permintaan dukungan manajemen untuk } \\
\text { menjamin kerjasama dan koordinasii } \\
\text { berbagai unit bisnis, untuk memfasilitasi } \\
\text { kelancaran transisi ke aplikasi. }\end{array}$ & 12 & $\begin{array}{l}\text { Informasi dikeluarkan tanpa } \\
\text { otorisasi yang tepat }\end{array}$ & INT & $\mathrm{C}$ \\
\hline \multirow[t]{3}{*}{40} & Kepemilikan kontrol. & 1 & $\begin{array}{l}\text { Informasi diakses oleh pihak } \\
\text { yang tidak berwenang }\end{array}$ & INT & $\mathrm{C}$ \\
\hline & & 3 & $\begin{array}{l}\text { Informasi digunakan dalam } \\
\text { konteks yang tidak sesuai }\end{array}$ & INT & $\mathrm{C}$ \\
\hline & & 9 & $\begin{array}{l}\begin{array}{l}\text { Prosedur otorisasi } \\
\text { perusahaan }\end{array} \\
\end{array}$ & INT & B \\
\hline
\end{tabular}




\begin{tabular}{|c|c|c|c|c|c|}
\hline \multirow[t]{3}{*}{41} & \multirow[t]{3}{*}{$\begin{array}{l}\text { Tim pengembang akan mengembangkan } \\
\text { strategi korektif seperti proses ulang, } \\
\text { merevisi/ merubah logika aplikasi, dll. }\end{array}$} & \multirow{2}{*}{$\begin{array}{c}8 \\
\\
18\end{array}$} & \multirow{2}{*}{$\begin{array}{l}\text { Penggunaan informasi yang } \\
\text { tidak benar yang dapat } \\
\text { berdampak pada bisnis } \\
\\
\begin{array}{l}\text { Data lama/dokumen tidak } \\
\text { dihapus }\end{array}\end{array}$} & \multirow{2}{*}{$\begin{array}{l}\text { INT } \\
\\
\text { INT }\end{array}$} & \multirow{2}{*}{ C } \\
\hline & & & & & \\
\hline & & 20 & $\begin{array}{ll}\begin{array}{l}\text { Kesalahan terhadap } \\
\text { dokumen } \\
\text { dipublikasikan }\end{array} & \text { yang } \\
\end{array}$ & INT & $\mathrm{C}$ \\
\hline 42 & $\begin{array}{lrr}\text { Produksi } & \text { kontrol migrasi } & \text { seperti } \\
\text { pencarian } & \text { dan } & \text { menghapus/ } \\
\text { menghilangkan proses } & \text { untuk memastikan } \\
\text { penyimpanan data yang bersih. }\end{array}$ & 31 & $\begin{array}{l}\text { Akses untuk backup data } \\
\text { tidak terkontrol dengan baik }\end{array}$ & $\mathrm{CON}$ & $\mathrm{D}$ \\
\hline \multirow[t]{16}{*}{43} & $\begin{array}{l}\text { Melakukan pemerikasaan secara rutin } \\
\text { (berkala) terhadap hardware, software, } \\
\text { dan sistem informasi yang ada. }\end{array}$ & 4 & $\begin{array}{l}\text { Data diperbarui } \\
\text { internal tapi tidak } \\
\text { eksternal }\end{array}$ & INT & $\mathrm{C}$ \\
\hline & & 9 & $\begin{array}{lll}\text { Prosedur otorisasi } & \text { pada } \\
\text { perusahaan } & & \\
\end{array}$ & INT & $\mathrm{B}$ \\
\hline & & 12 & $\begin{array}{l}\text { Informasi dikeluarkan tanpa } \\
\text { otorisasi yang tepat }\end{array}$ & INT & $\mathrm{C}$ \\
\hline & & 13 & $\begin{array}{l}\text { Kebocoran informasi internal } \\
\text { perusahaan }\end{array}$ & INT & $\mathrm{C}$ \\
\hline & & 17 & $\begin{array}{l}\text { Tidak adanya rekaman } \\
\text { terhadap } \\
\text { sistem/aplikasi software }\end{array}$ & INT & C \\
\hline & & 18 & $\begin{array}{l}\text { Data lama/dokumen tidak } \\
\text { dihapus }\end{array}$ & INT & $\mathrm{C}$ \\
\hline & & 19 & $\begin{array}{l}\text { Modifikasi } \\
\begin{array}{l}\text { anti } \\
\text { terhadap }\end{array} \\
\text { virus }\end{array}$ & INT & $\mathrm{C}$ \\
\hline & & 22 & Informasi/ data tidak benar & $\mathrm{CON}$ & $\mathrm{C}$ \\
\hline & & 26 & $\begin{array}{l}\text { Menggunakan sistem yang } \\
\text { rentan untuk mengirim data/ } \\
\text { informasi yang penting }\end{array}$ & $\mathrm{CON}$ & $\mathrm{D}$ \\
\hline & & 29 & $\begin{array}{lcr}\text { Otentikasi } & \text { untuk } & \text { akses } \\
\text { informasi } & \text { sensitif } & \text { tidak } \\
\text { memadai } & & \\
\end{array}$ & $\mathrm{CON}$ & $\mathrm{D}$ \\
\hline & & 31 & $\begin{array}{l}\text { Akses untuk backup data } \\
\text { tidak terkontrol dengan baik }\end{array}$ & $\mathrm{CON}$ & $\mathrm{D}$ \\
\hline & & 32 & Keamanan firewall diintrusi & $\mathrm{CON}$ & $\mathrm{D}$ \\
\hline & & 34 & $\begin{array}{l}\text { Hacker dapat membuat } \\
\text { sistem down }\end{array}$ & AVA & $\mathrm{C}$ \\
\hline & & 35 & $\begin{array}{l}\text { Situs hosting tidak memiliki } \\
\text { perlindungan fisik informasi }\end{array}$ & AVA & $\mathrm{C}$ \\
\hline & & 36 & $\begin{array}{l}\text { Hubungan jaringan antar } \\
\text { sistem gagal didalam } \\
\text { perusahaan }\end{array}$ & AVA & $\mathrm{C}$ \\
\hline & & 38 & $\begin{array}{l}\text { Kesalahan terhadap instalasi } \\
\text { software/hardware }\end{array}$ & AVA & $\mathrm{C}$ \\
\hline
\end{tabular}




\section{Implementasi Kontrol terhadap Resiko-resiko yang Masih Terbuka}

Pada tahap ini pimpinan proyek dan fasilitator akan bertemu dengan manajer bisnis untuk meninjau ulang, mengidentifikasi kontrol apa saja yang dapat digunakan untuk mengatasi resikoresiko yang masih terbuka. Menentukan control apa saja yang perlu dilakukan untuk menganggulangi resiko yang masih terbuka. Atau bahwa ternyata resiko tersebut tidaklah bersifat high impact sehingga bisnis manajer mengindikasikan resiko tersebut sebagai resiko yang dapat diterima.

\section{PENUTUP}

Melalui pendekatan FRAP terhadap proses penentuan resiko dan dampaknya, proses penentuan prioritas, dan proses penentuan kontrol pengamanan proses analisis resiko dapat dilakukan dalam hitungan hari, bukan mingguan atau bulanan. Dengan demikian analisis resiko bukan merupakan kendala, tetapi proses yang sangat mungkin dilakukan dan juga diperlukan. Di samping tidak begitu sulit untuk dilakukan, dengan pendekatan FRAP pemilik resiko turut serta dalam hal penentuan resiko dan prioritas resiko yang membuat pengukuran resiko menjadi lebih fokus dan terarah. Simpulan yang dapat diambil dari hasil penelitian di antaranya adalah: (1) penerapan teknologi informasi sudah memiliki peranan yang penting di dalam perusahaan; (2) perusahaan telah mengelola sistem keamanan jaringan dengan baik, ini dikarenakan jaringan perusahaan telah dipantau dan diaudit secara rutin. Walaupun ada sesekali kerusakan yang terjadi tetapi ini dapat ditanggulangi dengan baik; Kurangnya pengendalian internal dalam perusahaan, dalam hal pembuatan prosedur sistem aplikasi, yang saat ini sedang dalam proses pengembangan; (3) perusahaan sebaiknya membuat dokumentasi terhadap Disaster recovery Plan (DRP), untuk memudahkan perusahaan dalam menangani resiko yang muncul. Informasi dan sistem yang menjadi proses sumber daya ini adalah aset yang sangat penting dan utama untuk mendukung bisnis atau misi dari perusahaan apapun dan harus dilindungi. Suatu proses analisis resiko yang efektif menjamin bahwa kebutuhan bisnis dipenuhi.

\section{DAFTAR PUSTAKA}

Djojosoedarso, S. (2005). Prinsip-prinsip Manajemen Resiko Asuransi (edisi revisi). Jakarta: Salemba Empat.

Gondodiyoto, Sanyoto. (2009). Pengelolaan Fungsi Audit Sistem Informasi (edisi ke-2). Jakarta: Mitra Wacana Media.

O’Brien, James A. \& Marakas, George M. (2007). Management Information Systems (edisi ke-7). New York: McGraw-Hill.

Peltier, Thomas R. (2001). Information security Risk Analysis. Washington D.C: Auerbach/CRC Press. 